[4].Patent No. 142638. IPC7 G01D 45/14 (2006.01). Koaksial'nyy protypotokovyy rotatsiynyy pylovid-dil'nyk. [Coaxial counter-current rotational saw-cut] / S. I. Movchan, L. M. Datsenko, V. P. Skiba, N. V. Tarusova, A. O. Angelovska. u201910374; - app. 10/15/2019; publ. 06/25/2020, bul. No. 12. [in Ukraine].

[5].Patent № 147205. IPC B01D 45/14 45/14 (2006.01). Koaksial'nyy protypotokovyy rotatsiynyy pylo-viddil'nyk. [Coaxial counterflow rotary dust separator] / SI Movchan, VP Skiba, NM Voznyuk, OO Dereza, A. Yu. Yakunicheva; Owner: Tavriya State Agrotechnological University. Dmitry Motorny. - u202006663. - application 10/16/2020; publ. 21.04.2021, bul. № 16. [in Ukraine].

[6].Sandler, A. K., Opryshko, M. O. (2020). Volokonno-optycheskyy datchyk kontrolya sostoyanyya tekhnycheskykh zhyd-kostey y hazov. [Fiber-optic sensor for monitoring the state of technical liquids and gases] // X International Scientific and Methodological Conference "Ship Electrical Engineering, Electronics and Automation", 24.11.2020 November 25, 2020: conference materials. - Odessa: NU "OMA". - P. 63-68. [in Ukraine].

[7].Sandler, A. K. (2021). Metod pidvyshchennya efektyvnosti diahnostuvannya tekhnichnoho stanu sudnovykh hazoturbin-nykh ustanovok na osnovi volokonno-optychnykh tekhnolohiy. [Method of increasing the efficiency of diagnosing the technical condition of ship gas turbine plants on the basis of fiber-optic technologies]: dis. ... cand. tech. Science: 05.22.20. - Kyiv: - 159 p. [in Ukraine].

Отримана в редакції 10.08.2021. Прийнята до друку 25.08.2021. Received 10 August 2021. Approved 25 August 2021. Available in Internet 31 September 2021.

УДК [621.867.3:622.612]:658.5

\title{
ЗАМКНУТІ САР 3 ПРОГНОЗУВАННЯМ: АНАЛІЗ АЛЬТЕРНАТИВНИХ ВАРІАНТІВ СРУКТУР
}

\section{Степанов М.Т.}

OHАХТ (Україна)

ORCID: https://orcid.org/0000-0003-1297-5537

E-mail: stepanov197818@gmail.com

Copyright (C) 2021 by author and the journal “Automation of technological and business - processes”. This work is licensed under the Creative Commons Attribution International License (CC BY). http://creativecommons.org/licanses/by/4.0

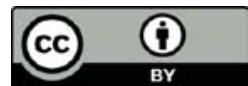

ONAFT

Open Access

DOI:

Анотація. У статті розглядається системи автоматичного регулювання які реалізують алгоритми керування 3 прогнозуванням складових вільного та вимушеного руху на час запізнення вперед в замкнутому контурі. Проводиться порівняльний аналіз їх роботи у перехідних та сталих режимах роботи, а також запасів стійкості які вони забезпечують. Об'єкти технологічного типу досить часто мають велику інериійність в каналах регулювання яка пов'язаної не тільки з чистим запізненням, але, більшою мірою з акумуляцією речовини і енергії, так званим ємнісним запізненням. Повна або часткова компенсачія иієї інериійності може в значній мірі поліпшити якість регулювання для таких об'єктів. На практиці для компенсації впливу запізнення на динаміку власного руху часто використовують системи з упереджувачем Сміта які значно розширюють запас стійкості систем і забезпечують їх працездатність в умовах нестаціонарних властивостей об'єкта керування. Також прогнозування використовується у системах керування з прогнозуючою моделлю, в яких керуючий вплив на кожному кроці розраховується за рахунок вирішення оптимізаційної задачі на основі математичної моделі об'єкта керування. Ці системи також застосовують для керування об'єктами технологічного типу, зокрема рекомендують до застосування при керуванні багатоканальними об'єктами канали яких пов'язані між собою через дію перехресних зв'язків. В якості альтернативи вказаним системам запропонована система регулювання з прогнозуванням вимушеного руху в замкнутий контур якої введено алгоритм прогнозування в реальному часі на основі кубічного сплайну. Проведено структурний та оптимальний параметричний синтез альтернативних варіантів систем автоматичного регулювання. $B$ якості базового регулятора було обрано типовий ПІД-регулятор. Порівняльний аналіз оптимальних систем, проведений в часовій $i$ частотних областях, показав перевагу системи регулювання, щзо реалізує принцип керування за прогнозом на основі кубічного сплайну. При аналізі роботи систем за каналом дї неконтрольованих збурень система регулювання з прогнозуванням по кубічному сплайну забезпечує зниження інтегрального $і$ прямих показників якості перехідних процесів до 40\%. Перевірка на грубість систем автоматичного регулювання показала, що система автоматичного регулювання з прогнозуванням регульованої змінної за кубічним сплайном має приблизно однаковий запас стійкості за часом запізнення та трошки нижчий запас стійкості за коефіцієнтом передачі об'єкта керування, ніж система з упереджувачем Сміта. 
Abstract. The article considers automatic control systems that implement control algorithms with prediction of the components of free and forced motion for the time of delay in a closed loop. A comparative analysis of their work in transient and stable modes of operation, as well as the reserves of stability that they provide. Objects of a technological type quite often have a large inertia in the control channels associated not only with a pure delay, but, to a greater extent, with the accumulation of matter and energy, the so-called capacitive delay. Full or partial compensation of this inertia can significantly improve the quality of regulation for such objects. In practice, Smith's anticipatory systems are often used to compensate for the effect of the delay on the dynamics of self-motion, which significantly expand the stability of the systems and ensure their operability in conditions of non-stationary properties of the control object. Forecasting is also used in control systems with a predictive model, in which the control effect at each step is calculated by solving an optimization problem based on a mathematical model of the control object. These systems are also used for the control of technological objects, in particular, recommended for use in the control of multi-channel objects whose channels are interconnected through the action of cross-links. As an alternative to these systems, a control system with predicted forced motion in a closed loop is proposed, which introduces a real-time prediction algorithm based on a cubic spline. The structural and optimal parametric synthesis of alternative variants of automatic control systems is carried out. A typical PID controller was chosen as the basic controller. Comparative analysis of optimal systems, conducted in the time and frequency domains, showed the advantage of the control system, which implements the principle of control by forecast based on the cubic spline. When analyzing the operation of systems along the channel of action of uncontrolled perturbations, the control system with prediction of the cubic spline provides a reduction of integrated and direct quality indicators of transients up to 40\%. A check on the roughness of the automatic control systems showed that the automatic control system with prediction of the variable on the cubic spline has approximately the same margin of safety over dead time and a slightly lower margin of stability for the transfer factor of the control object than the Smith biased system.

Ключові слова: прогнозування, кубічний сплайн, прогнозуюча модель, система автоматичного регулювання, запас стійкості

Keywords: prediction, cubic spline, prediction model, automatic control system, robust control.

\section{Вступ}

Основними характеристиками замкнутих САР є якість регулювання і стійкість. Якість регулювання визначається динамічної та статичної точністю САР. Максимально досяжна динамічна точність САР багато в чому обмежується запізненням і інерційністю каналів об'єкта керування. Об'єкти технологічного типу досить часто мають велику інерційністю в каналах регулювання, пов'язаної не тільки з чистим запізненням, але, більшою мірою з акумуляцією речовини і енергії, так званим ємнісним запізненням. Повна або часткова компенсація цієї інерційності може в значній мірі поліпшити якість регулювання для таких об'єктів. На практиці для компенсації впливу запізнення на динаміку власного руху часто використовують системи з упереджувачем Сміта [1] які значно розширюють запас стійкості систем i забезпечують їх працездатність в умовах нестаціонарних властивостей об'єкта керування. Також прогнозування використовується у системах керування з прогнозуючою моделлю (Model Predictive Control) [2], в яких керуючий вплив на кожному кроці розраховується за рахунок вирішення оптимізаційної задачі на основі математичної моделі об'єкта керування. Ці системи також застосовують для керування об'єктами технологічного типу, зокрема рекомендують до застосування при керуванні багатоканальними об'єктами канали яких пов'язані між собою через дію перехресних зв'язків. В якості альтернативи вказаним системам запропонована система регулювання 3 прогнозуванням вимушеного руху в замкнутий контур якої введено алгоритм прогнозування у (t) в реальному часі на основі кубічного сплайну. В запропонованій САР виконано перехід від загальноприйнятого принципу регулювання по поточному значенню вихідної величини у $(\mathrm{t})$ до принципу регулювання за прогнозом $\mathrm{y}\left(\mathrm{t}+\tau_{\text {пр }}\right)$. Це означає що обчислення керуючого впливу (положення регулюючого органу) U (t) проводиться не за поточним значенням регульованої величини у $(\mathrm{t})$, а по прогнозованому значенню $\mathrm{y}\left(\mathrm{t}+\tau_{\text {пр }}\right)$ у майбутньому.

Аналіз літературних даних і постановка проблеми

Аналіз сучасних підходів [2,3,4] підтверджує актуальність використання прогнозування в алгоритмах керування сучасних САР. Прогнозування в САР може здійснюватися за різними методами.

Керування 3 прогнозуючою моделлю (МРС) використовується у переробній промисловості на хімічних та нафтопереробних заводах починаючи з 1980-х років. В останні роки цей метод керування також використовується в системах балансування енергосистем, в силовій електроніці [2], у системах перетворення енергії вітру [3] та на підприємствах по очищенню стічних вод [3]. В алгоритмах МРС використовуються динамічні моделі процесів, частіше за всього лінійні емпіричні моделі які отримані шляхом ідентифікації моделі об’єкта керування (ОК). Для спрощеної моделі об'єкта і початкових умов виконується прогнозування поведінки під впливом керуючого сигналу на деякому кінцевому відрізку часу, званому горизонт прогнозу (Prediction Horizon). Виконується оптимізація керуючого сигналу з урахуванням всього комплексу обмежень, накладених на керуючі і регульовані змінні знаходиться оптимальне керування. На часовому відрізку, визначеному одним кроком обчислення який становить фіксовану малу частину горизонту прогнозу, званому горизонтом керування (Control Horizon), реалізується знайдене оптимальне керування. По закінченню інтервалу здійснюється вимір фактичного стану, які приймаються за нові початкові умови. Горизонт прогнозу зсувається на крок вперед, і знов повторюються етапи розрахунку керуючої дії. Використання MPC для керування промисловими об'єктами підтримується зокрема фірмою Siemens у бібліотеці підпрограм SIMATIC PCS7 APC-Library (Advanced Process Library) яка розповсюджується для відомого середовища розробки прикладного програмного забезпечення - PCS 7. Також цією бібліотекою підтримується реалізація систем 
регулювання 3 упереджувачем Сміта. Системи 3 упереджувачем Сміта часто застосовуються для керування нестаціонарними об'єктами харчової промисловості з запізненням в каналах керування [1]. Розглянуті алгоритми розширюють запас стійкості систем і забезпечують зниження помилок відтворення більш ефективно ніж помилок стабілізації.

Результати досліджень [4-7] показують що для керування об’єктами технологічного типу можна також запропонувати систему регулювання з прогнозуванням вимушеного руху в замкнутий контур якої введено алгоритм прогнозування у (t) в реальному часі. Регульовану змінну у (t) в об’ єктах технологічного типу відфільтровану від шумів можна розглядати як багатократно диференційовану функцію часу i вести прогнозування іiі значень у реальному часі на основі, наприклад, кубічного сплайну. Таким чином ми отримуємо САР в якій виконано перехід від загальноприйнятого принципу регулювання по поточному значенню вихідної величини у (t) до принципу регулювання за прогнозом $\mathrm{y}\left(\mathrm{t}+\tau_{\text {пр }}\right)$. Оцінити ефективність такої системи в порівнянні з системами на базі алгоритмів MPC та упереджувача Сміта є завданням даного дослідження.

Мета та задачі дослідження

Метою дослідження є визначення динамічної точності і запасу стійкості САР яка реалізує принцип керування за прогнозом на основі кубічного сплайну для об’єктів технологічного типу в порівнянні з САР з упереджувачем Сміта та системами керування з прогнозуючою моделлю. Для досягнення визначеної мети необхідно провести структурний і оптимальний параметричний синтез САР з упереджувачем Сміта і 3 прогнозуючою моделлю та САР яка реалізує принцип керування за прогнозом. Після цього провести порівняльний аналіз цих систем.

\section{Методи і матеріали досліджень}

Для проведення досліджень в якості основного методу будемо використовувати метод імітаційного моделювання в середовищі Simulink системи Matlab. Для цього на першому етапі розробимо структурні схеми САР, визначимо регулятор, віртуальний тестовий ОК (ВТОК), критерій оцінки якості роботи САР, модель упереджувача Сміта і проведемо для моделі кубічного сплайна розрахунок співвідношень, що дозволяють оцінювати його параметри в реальному часі і вести розрахунок прогнозного значення регульованої змінної. Структурні схеми САР яка реалізує принцип керування за прогнозом, САР з упереджувачем Сміта та САР з прогнозуючою моделлю наведені на рис.1.

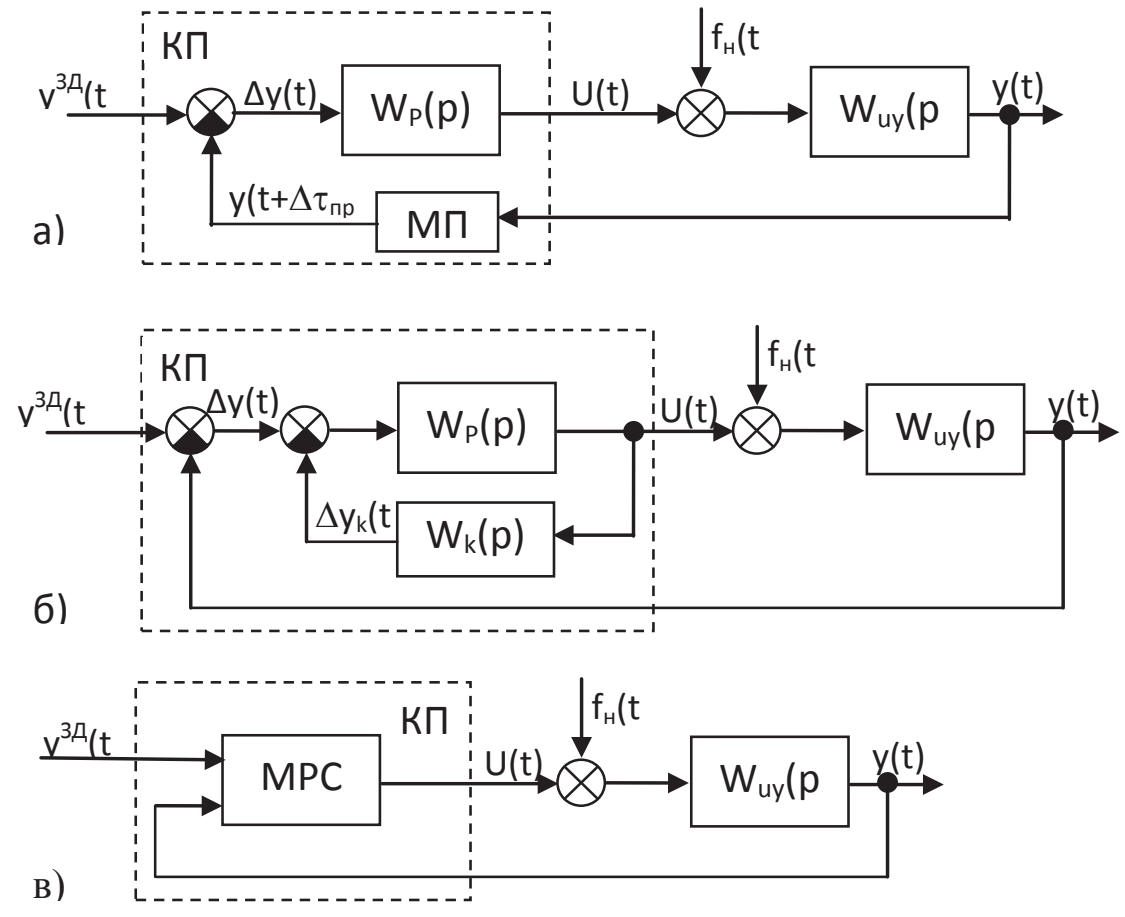

Рис. 1 - Структурні схеми САР з модулем прогнозування в її контурі зворотного зв'язку (a), з упереджувачем Сміта (б), з прогнозуючою моделлю (в) ( $W_{p}(p)$ - передаточна функція ПІД регулятора; $\mathrm{W}_{\text {uy }}(\mathrm{p})$ - передаточна функція ОК за каналом керування; $\mathrm{MП}$ - модуль прогнозування; $\mathrm{W}_{\mathrm{k}}(\mathrm{p})$ - передаточна функція упереджувача Сміта; МРС - регулятор з прогнозуючою моделлю).

В якості регулятора будемо використовувати ПІД - регулятор з реальним диференціатором. Для проведення оптимального параметричного синтезу САР i оцінки якості іiі роботи в перехідних режимах скористаємося інтегральним квадратичним показником якості (1), а оцінку якості її роботи в сталих режимах будемо проводити за показником (2): 


$$
\begin{aligned}
& I_{1}=\int_{\mathrm{t}_{1}}^{\mathrm{t}_{1}+\text { Тмод }}\left(\mathrm{y}^{\text {зд }}(\mathrm{t})-\mathrm{y}(\mathrm{t})\right)^{2} \mathrm{dt}, \\
& \mathrm{I}_{2}=\sqrt{\frac{1}{\mathrm{~T}_{\text {мод }}} \int_{\mathrm{t}_{1}}^{\mathrm{t}_{1}+\text { Тмод }}\left(\mathrm{y}_{\text {зд }}(\mathrm{t})-\mathrm{y}(\mathrm{t})\right)^{2} \mathrm{dt},},
\end{aligned}
$$

де $\mathrm{T}_{\text {мод }}$ - час моделювання, $\mathrm{t}_{1}$ - час початку відліку,

Модель об'єкта керування розглянемо зі статичними властивостями за каналом керування. Передаточна функція віртуального тестового ОК (ВТОК) має наступний вигляд.

$$
\mathrm{W}_{\mathrm{uy}}^{o}(\mathrm{p})=\frac{\mathrm{ko}}{(\mathrm{T} 1 \mathrm{p}+1)^{6}(\mathrm{~T} 2 \mathrm{p}+1)}
$$

де Т1 - постійна часу що характеризує ємнісне запізнення, Т2 - постійна часу, ко - коефіцієнт передачі ОК. При цьому постійна часу Т1 << Т2. Для проведення досліджень були прийняті наступні базові значення параметрів ВТОУ: $\mathrm{T} 1=0.5, \mathrm{~T} 2=7, \mathrm{ko}=1.2$.

На рис.2 представлена нормована перехідна характеристика ВТОУ по каналу керування з ілюстрацією процедури параметричної ідентифікації моделі першого порядку за методикою Мініної.

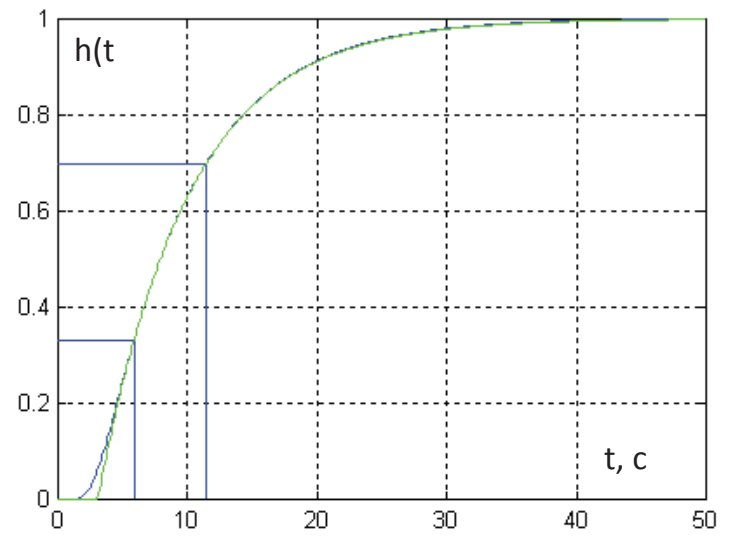

Рис. 2 - Ілюстрація процедури параметричної ідентифікації моделі ОК (методика Мініной) за каналом керування.

Передаточна функція моделі першого порядку по каналу керування.

$$
\mathrm{W}_{\text {uy }}(\mathrm{p})=\frac{1.2 e^{-3.1 p}}{7 p+1}
$$

Передаточна функція упереджувача Сміта прийме наступний вигляд.

$$
\mathrm{W}_{\mathrm{k}}(\mathrm{p})=\frac{k_{o}\left(1-e^{-\tau_{o} p}\right)}{T_{o} p+1}=\frac{1.2\left(1-e^{-3.1 p}\right)}{7 p+1}
$$

Модуль прогнозування по кубічному сплайну будемо реалізовувати на основі наступного виразу:

$$
\begin{gathered}
\mathrm{y}\left(\mathrm{t}+\Delta \tau_{\text {iр }}\right)=\bar{y}(\mathrm{t})+\mathrm{d}(\mathrm{t})\left(\mathrm{t}+\Delta \tau_{\text {iр }}\right)^{3}+\mathrm{c}(\mathrm{t})\left(\mathrm{t}+\Delta \tau_{\text {тр }}\right)^{2}+\mathrm{b}(\mathrm{t})\left(\mathrm{t}+\Delta \tau_{\text {тр }}\right)+\mathrm{a}(\mathrm{t}), \\
\Delta \tau_{\text {пр }} \in\left[0, \tau_{\text {пр }}\right] .
\end{gathered}
$$

Тоді, якщо вдасться знайти значення трьох похідних цих оцінок в момент часу $\mathrm{t}=\mathrm{t}_{0}$, то оцінки значень коефіцієнтів в (6) визначаються з простих і зручних для розрахунку в реальному часі співвідношень:

$$
\begin{gathered}
\mathrm{d}\left(\mathrm{t}_{0}\right)=\dddot{\mathrm{y}}\left(\mathrm{t}_{0}\right) / 6, \\
\mathrm{c}\left(\mathrm{t}_{0}\right)=\left(\ddot{\mathrm{y}}\left(\mathrm{t}_{0}\right)-\dddot{\mathrm{y}}\left(\mathrm{t}_{0}\right) \mathrm{t}_{0}\right) / 2, \\
\mathrm{~b}\left(\mathrm{t}_{0}\right)=\dot{\mathrm{y}}\left(\mathrm{t}_{0}\right)-\ddot{\mathrm{y}}\left(\mathrm{t}_{0}\right) \mathrm{t}_{0}+\dddot{\mathrm{y}}\left(\mathrm{t}_{0}\right) \mathrm{t}_{0}^{2} / 2, \\
\mathrm{a}\left(\mathrm{t}_{0}\right)+\overline{\mathrm{y}}\left(\mathrm{t}_{0}\right)=\mathrm{y}\left(\mathrm{t}_{0}\right)-\dot{\mathrm{y}}\left(\mathrm{t}_{0}\right) \mathrm{t}_{0}+\ddot{\mathrm{y}}\left(\mathrm{t}_{0}\right) \mathrm{t}_{0}^{2} / 2-\dddot{\mathrm{y}}\left(\mathrm{t}_{0}\right) \mathrm{t}_{0}^{3} / 6,
\end{gathered}
$$

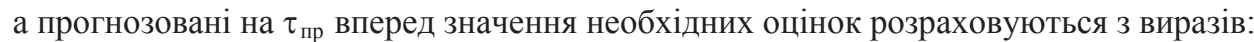




$$
\mathrm{y}\left(\mathrm{t}_{0}+\tau_{\text {пр }}\right)=\mathrm{d}\left(\mathrm{t}_{0}\right)\left(\mathrm{t}_{0}+\tau_{\text {пр }}\right)^{3}+\mathrm{c}\left(\mathrm{t}_{0}\right)\left(\mathrm{t}_{0}+\tau_{\text {пр }}\right)^{2}+\mathrm{b}\left(\mathrm{t}_{0}\right)\left(\mathrm{t}_{0}+\tau_{\text {пр }}\right)+\mathrm{a}\left(\mathrm{t}_{0}\right)+\overline{\mathrm{y}}\left(\mathrm{t}_{0}\right)
$$

Необхідною умовою роботи алгоритму, $є$ щоб $\mathrm{y}(\mathrm{t})$ була триразово диференційованою. Ця умова цілком здійсненна, так як змінні на виході ОК, відфільтровані від шумів, як правило, є багато разів диференційованими.

У розглянутому сплайні розрахунок коефіцієнтів ведеться в припущенні, що в момент $\mathrm{t}_{0}$ відомі значення самої змінної і всіх необхідних похідних. У разі цифрової реалізації алгоритму керування, а саме вона передбачається як основна, похідні обчислюються за значеннями решітчастої функції $\mathrm{f}_{\mathrm{k}}\left(\mathrm{nT}_{\mathrm{KB}}\right), n=\overline{0, \infty}, 3$ кроком квантування $\mathrm{T}_{\text {кв }}$.

Для проведення порівняльного аналізу роботи САР введемо такі позначення: САРП_К - САР реалізує принцип управління за прогнозом на основі кубічного сплайну (8); САР_УС - САР реалізує принцип управління за станом 3 упереджувачем Сміта (5); САР_МРС - САР реалізує принцип управління з прогнозуючою моделлю.

На першому етапі досліджень проведемо оптимальний параметричний синтез (ОПС) САР за критерієм (1) при фіксованих параметрах моделі ОУ без модулів прогнозування. А потім в замкнутий контур отриманої САР 3 оптимальними параметрами регулятора введемо модулі прогнозування 3 лінійним прогнозом і прогнозом по кубічному сплайну та упереджував Сміта. Налаштування САР_MPC проведемо інтегруючи модель ОК (4) в алгоритм MPC реалізований в Simulink. Схеми моделювання САР 3 ПІД регулятором і результати оптимального параметричного синтезу представлені на рис.3.
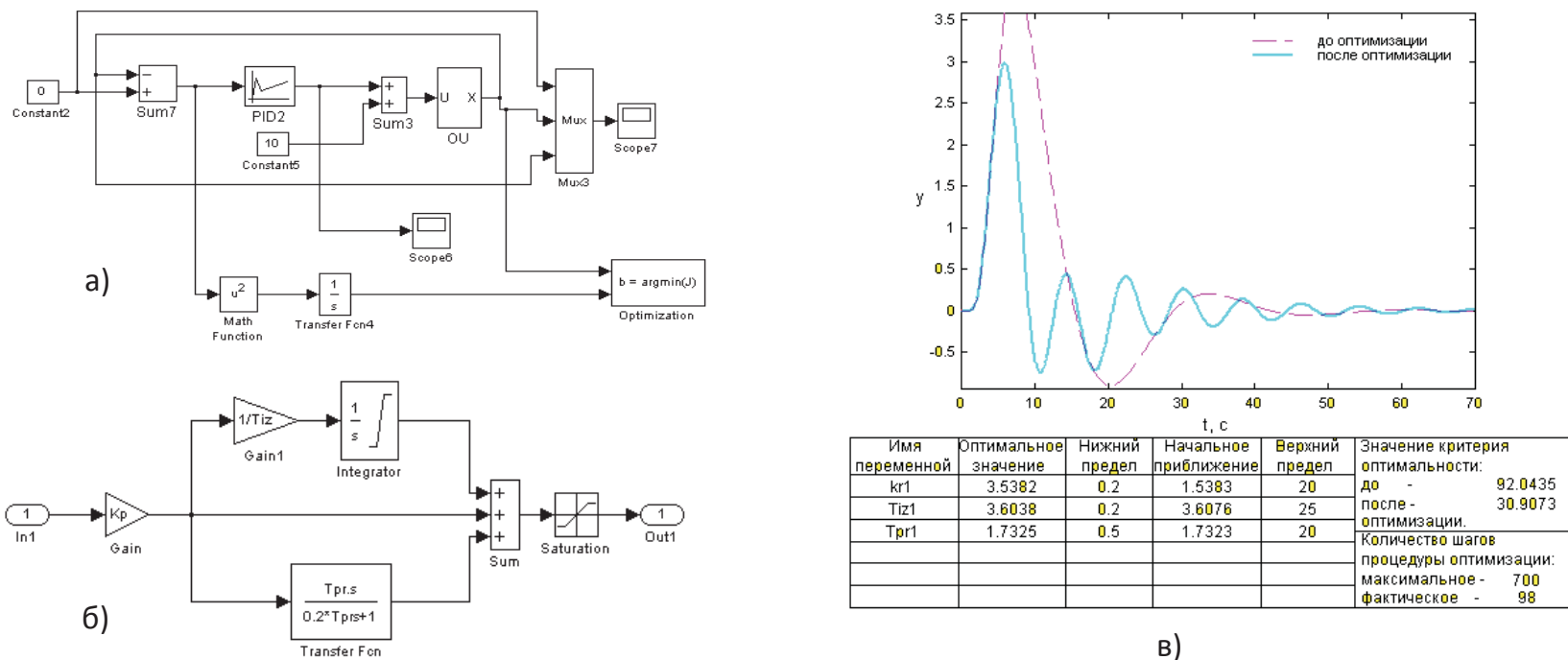

B)

Рис. 3 - Схема моделювання САР (а) з розкритою підсистемою ПІД регулятора (б), результати їі оптимального параметричного синтезу (в) при фіксованих значеннях параметром моделі ВТОК.

Для дослідження роботи систем у сталих режимах роботи була сформована модель неконтрольованих збурень у вигляді випадкового процесу. Реалізація випадкового процесу і його імовірнісні статичні та динамічні характеристики наведено на рис.4.
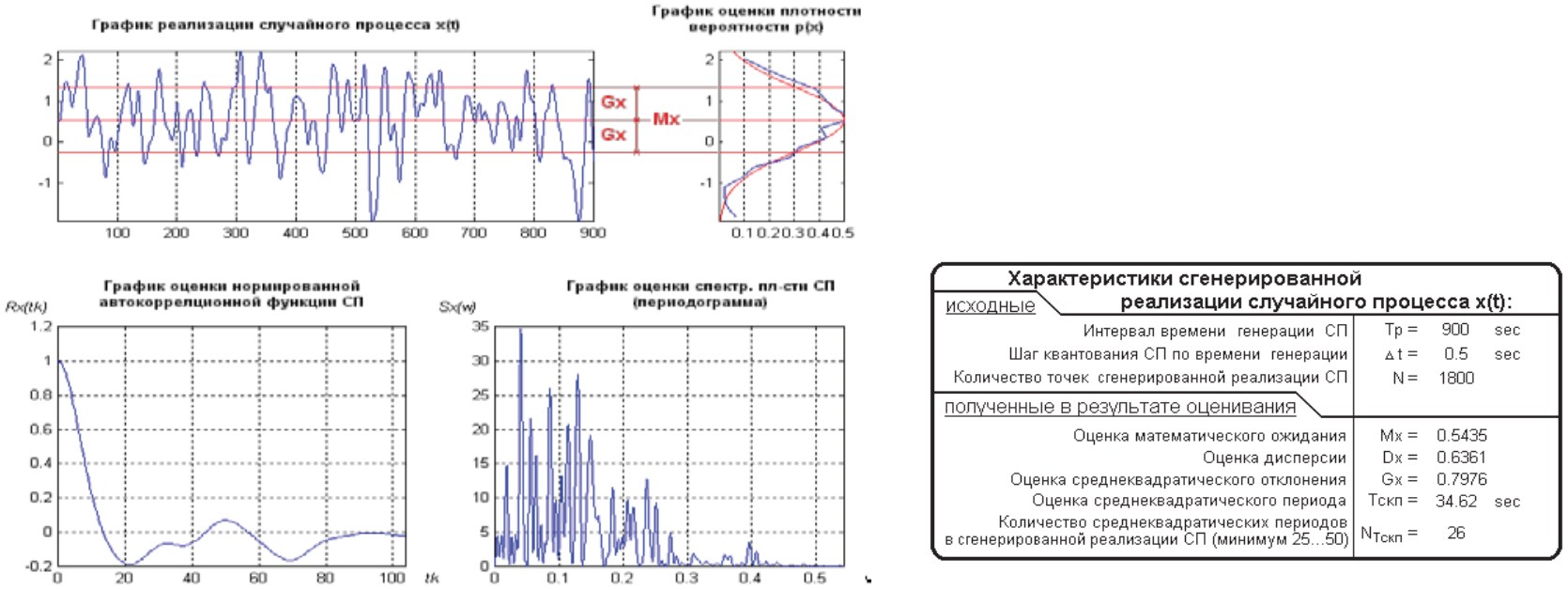

Рис. 4 - Реалізація неконтрольованих збурень та їх імовірнісні характеристики. 


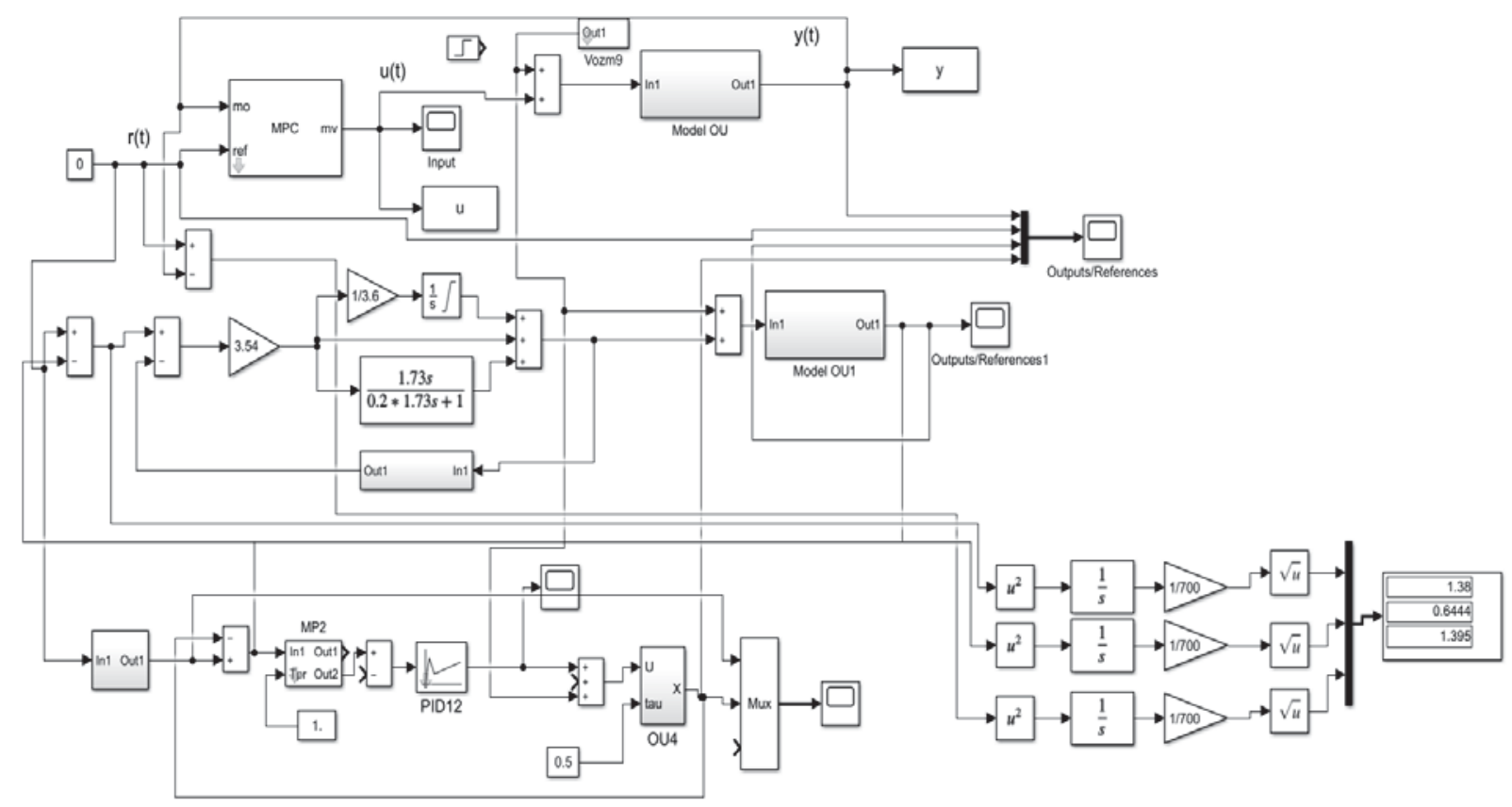

Рис. 5 - Схема моделювання для проведення порівняльного аналізу роботи досліджуваних САР.

\section{Результати досліджень та їх обговорення}

На рис. 4 представлені перехідні характеристики САР, а на рис.5 результати моделювання у сталих режимах роботи при дії неконтрольованих збурень випадкового характеру. За результатами моделювання бачимо що САР 3 прогнозуючою моделлю та упереджувачем Сміта мають схожі динамічні властивості. Це обумовлено використанням в обох алгоритмах керування однакової моделі ОК для прогнозування керуючої дії. Система 3 алгоритмом прогнозування на основі кубічного сплайну забезпечує більшу динамічну точність за каналом дії неконтрольованих збурень. Максимальне динамічне відхилення у перехідних режимах роботи та середньоквадратичне відхилення у сталих режимах роботи приблизно у двічі менше ніж у системах з прогнозуючою моделлю та упереджувачем Сміта. Але запаси стійкості за коефіцієнтом передачі та часом запізнення у цих систем набагато більші.

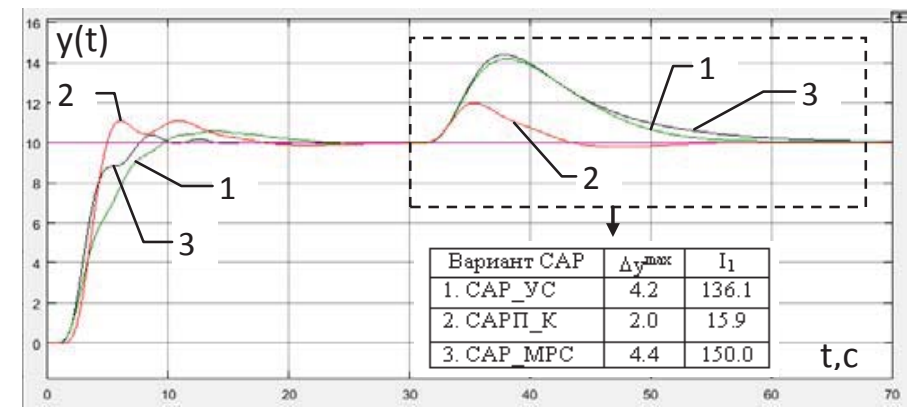

Рис.6 - Перехідні характеристики досліджуваних варіантів САР

(1 - CAP_УC, 2 - СAPП_K, 3 - CAP_MPC).

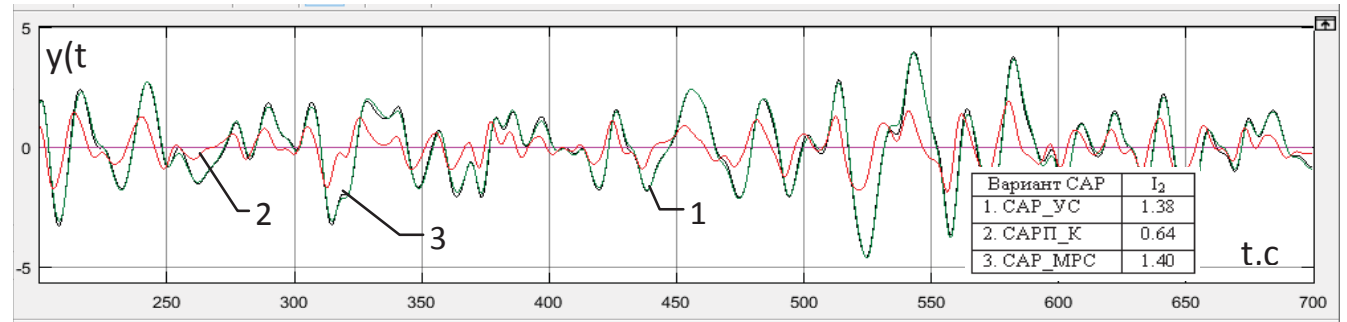

Рис. 7 - Результати моделювання САР у сталому режимі роботи при дії випадкових неконтрольованих збурень (1 - CAP_УC, 2-CAPП_K, 3 - CAP_MPC). 


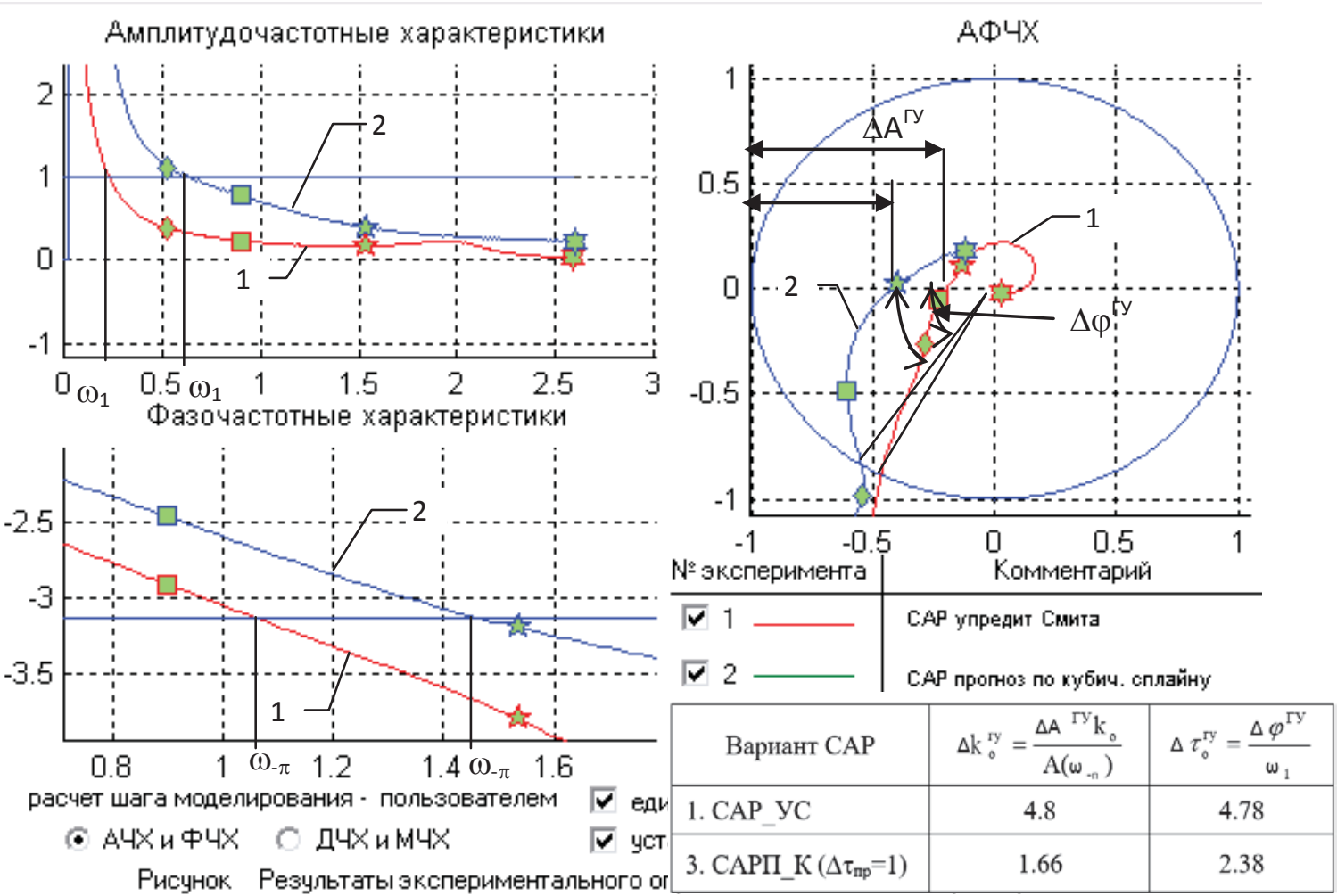

Рис. 8 - Частотні характеристики розімкнутих САР з розрахунком значень їх запасів стійкості за коефіціснтом передачі $\Delta \mathrm{k}_{\mathrm{o}}^{\text {гу }}$ і часом запізнення $\Delta f^{\mathrm{y}}$ в моделі ОК (1-САР_УС, 2-CАРП_К).

Отримані результати є попередніми і не дозволяють зробити висновок про перевагу одного з варіантів систем. Для більш точної оцінки ефективності роботи розглянутих варіантів систем проведемо їх ОПС в однакових умовах і проаналізуємо їх роботу.

Налаштування САР 3 прогнозуючою моделлю проводимо 3 використанням існуючого в системі Маtlab програмного інструментального засобу рис.9. Налаштування САР фактично зводиться до вибору вагових коефіцієнтів у критерії який використовується для вирішення задачі оптимізації в алгоритмі МРС.

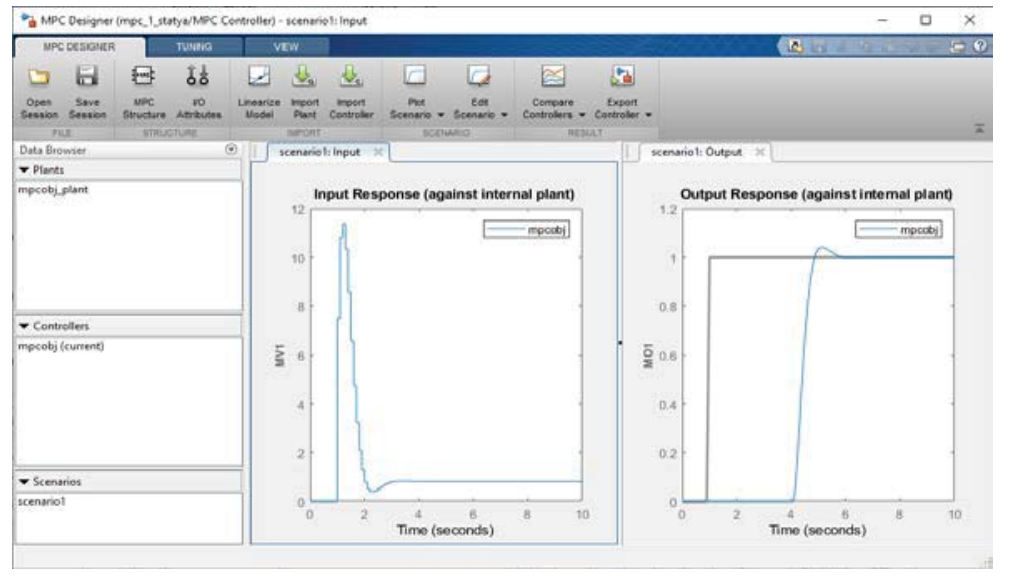

Рис. 9 - Головне вікно програми налаштування САР з прогнозуючою моделлю (МРС).

Проведене налаштування з використанням штатної програми не дозволило значно покращити динамічну точність САР за каналом дії неконтрольованих збурень і зменшити похибки стабілізації. Зміна налаштувань може приводити до значного збільшення часу перехідного процесу (рис. 10 (а)), чи наближувати систему до межі стійкості (рис. 10 (б)). Тому у подальших дослідженнях направлених на зменшення похибок стабілізації будемо розглядати тільки системи САР_УС та САРП_К. 

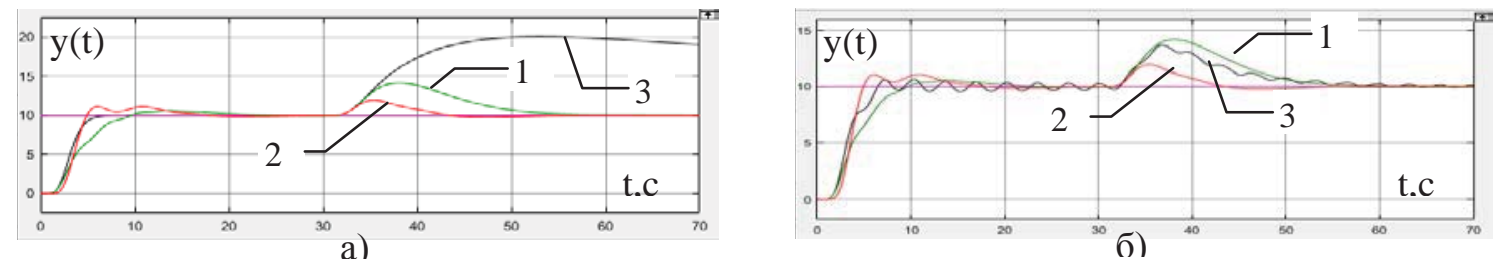

Рис. 10 - Перехідні характеристики досліджуваних варіантів САР при різних налаштуваннях алгоритму МРС. (1 - CAP_УC, 2 - САPП_К, 3 - CAP_MPC).

Об'єкти технологічного типу мають значний рівнем невизначеності і нестаціонарності їх параметрів. Тому оптимальний параметричний синтез САР будемо проводити в умовах параметричної невизначеності моделі ОК. В цьому випадку параметри моделі ОУ будуть задано не фіксованими значеннями, а діапазонами їх зміни $\mathrm{ko} \in[0.96 \ldots 1.44], \mathrm{T} 1 \in[0.4 \ldots 0.6]$. ОПС в умовах параметричної невизначеності моделі ОК дозволить забезпечити стійкість САР для заданого діапазону зміни параметрів ОУ і приблизно однаковий запас стійкості САР за коефіцієнтом передачі і часу запізнювання. На рис. 11 і 12 представлені результати ОПС САРП_К і САР_УС, а також результати перевірки цих систем на грубість, що підтверджують їх стійкість і працездатність в заданому діапазоні зміни параметрів ОК.
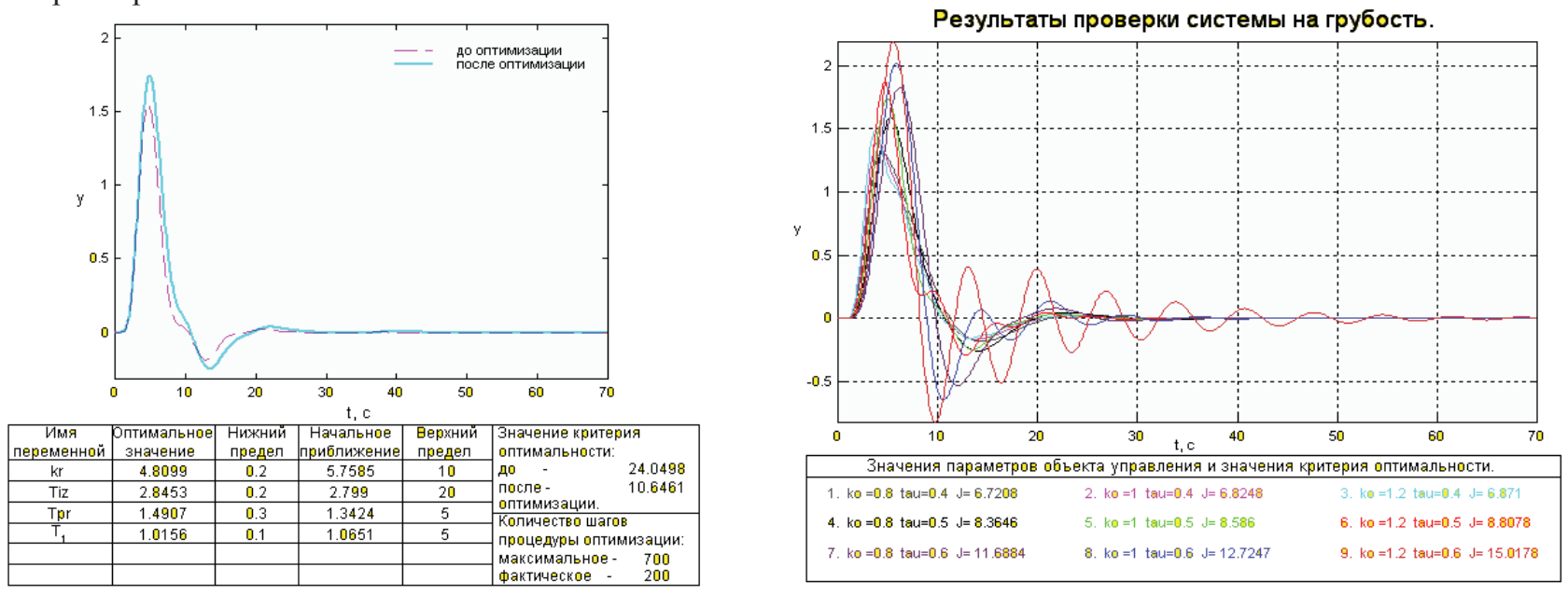

Рис. 11 - Результати оптимального параметричного синтезу і перевірки грубості САР з ПІД регулятором яка реалізус принцип управління за прогнозом на основі кубічного сплайну.
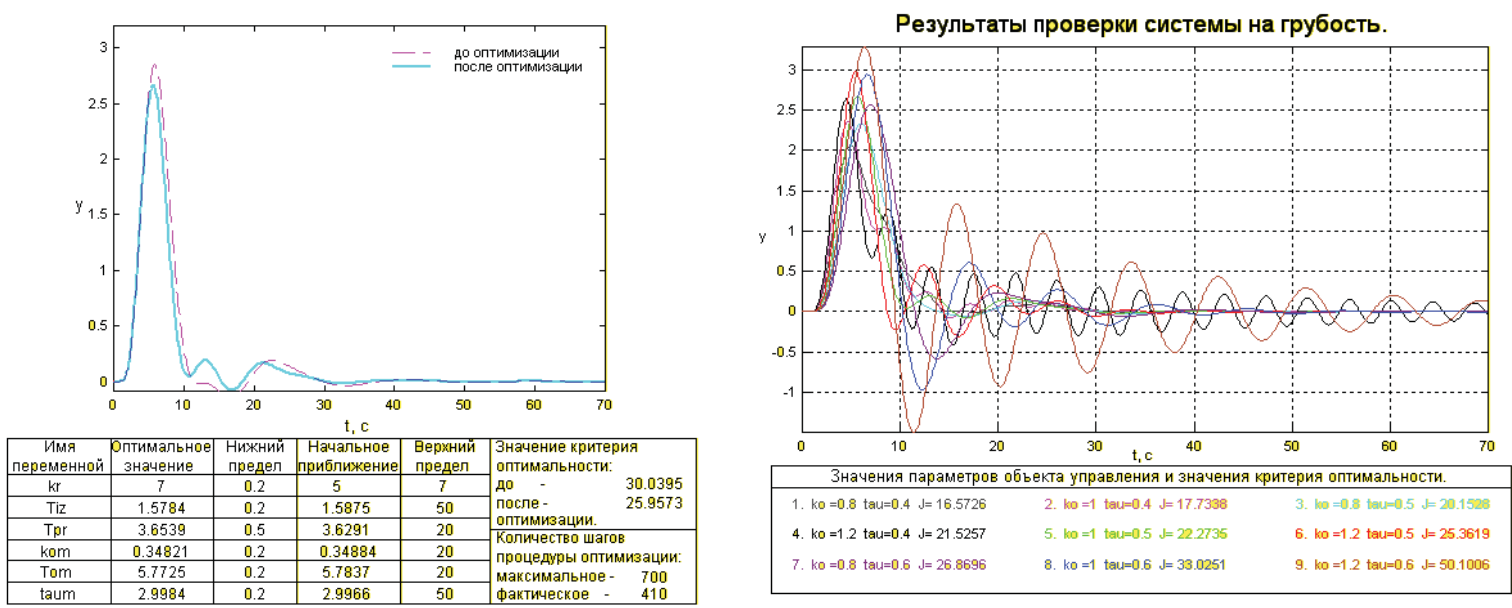

Рис. 12 - Результати оптимального параметричного синтезу і перевірки грубості САР з ПІД регулятором яка реалізус принцип управління за відхиленням з упереджувачем Сміта.

Проведемо порівняльний аналіз отриманих САР при номінальних значеннях параметрів ОК. На рис. 13 представлені перехідні характеристики САР, а на рис.14 результати моделювання у сталих режимах роботи при дії неконтрольованих збурень випадкового характеру. За результатами моделювання бачимо що САР 3 алгоритмом прогнозування на основі кубічного сплайну забезпечує більшу динамічну точність за каналом дії неконтрольованих збурень ніж САР 3 упереджувачем Сміта. Максимальне динамічне відхилення у перехідних режимах роботи приблизно на 40\% менше,а інтегрально-квадратичний критерій $\mathrm{I}_{1}$ менше майже у три рази. У сталих режимах роботи 
САР 3 алгоритмом прогнозування на основі кубічного сплайну також забезпечує приблизно 40\% зниження значення критерію $\mathrm{I}_{2}$ в порівнянні 3 системою 3 упереджувачем Сміта. На рис. 15 наведені частотні характеристики розімкнених CAP і розрахункові значення запасів стійкості систем за коефіцієнтом передачі $\Delta \mathrm{k}_{\mathrm{o}}^{\text {rу }} \mathrm{i}$ часом запізнення $\Delta \mathfrak{f y}^{\mathrm{y}}$. Значення запасів стійкості досліджуваних варіантів САР близькі один до одного. Тобто САР 3 алгоритмом прогнозування на основі кубічного сплайну при однакових запасах стійкості може забезпечити більш високу динамічну точність стабілізації регульованої змінної на заданому значенні.

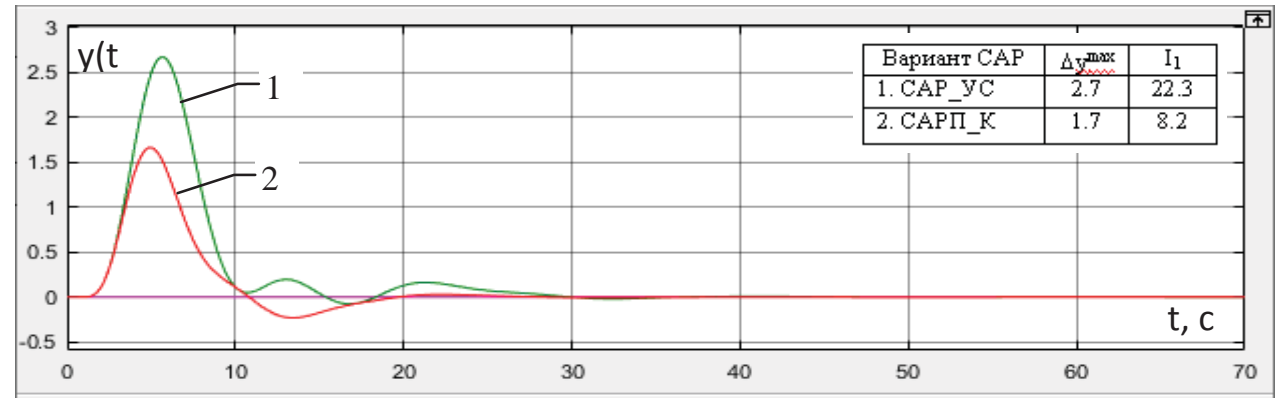

Рис. 13 - Перехідні характеристики САР при номінальних значеннях параметрів ОК. (1 - CAP_УC, 2 - САРП_K).

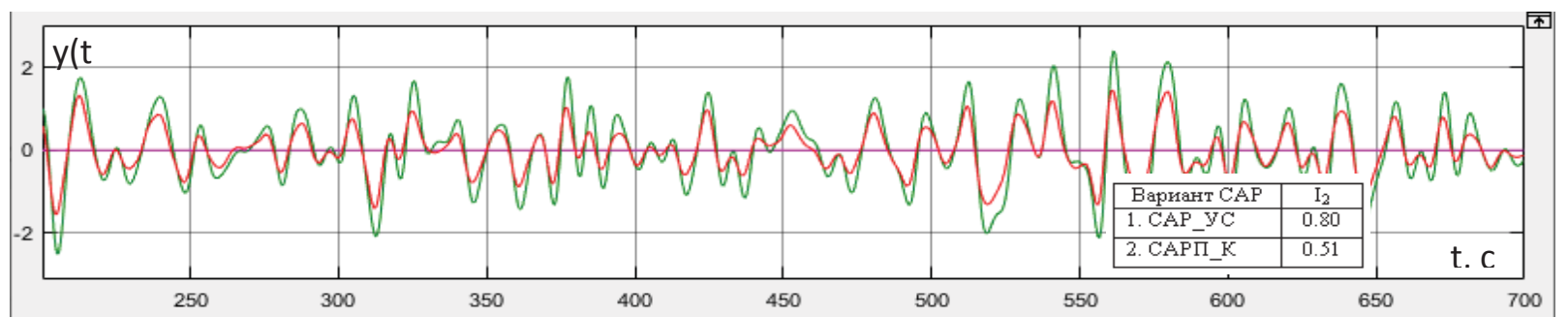

Рис. 14 - Результати моделювання САР у сталому режимі роботи при дії випадкових неконтрольованих збурень (1 - CAP_УC, 2-CAPП_К).

Ефективність придушення неконтрольованих збурень САРП_К підтверджується і частотними характеристиками замкнутих САР (рис. 16). На середньоквадратичні частоті неконтрольованих збурень значення АЧХ цієї системи значно менше ніж звичайної САР та САР_УС.

Амплитудочастотные характеристики
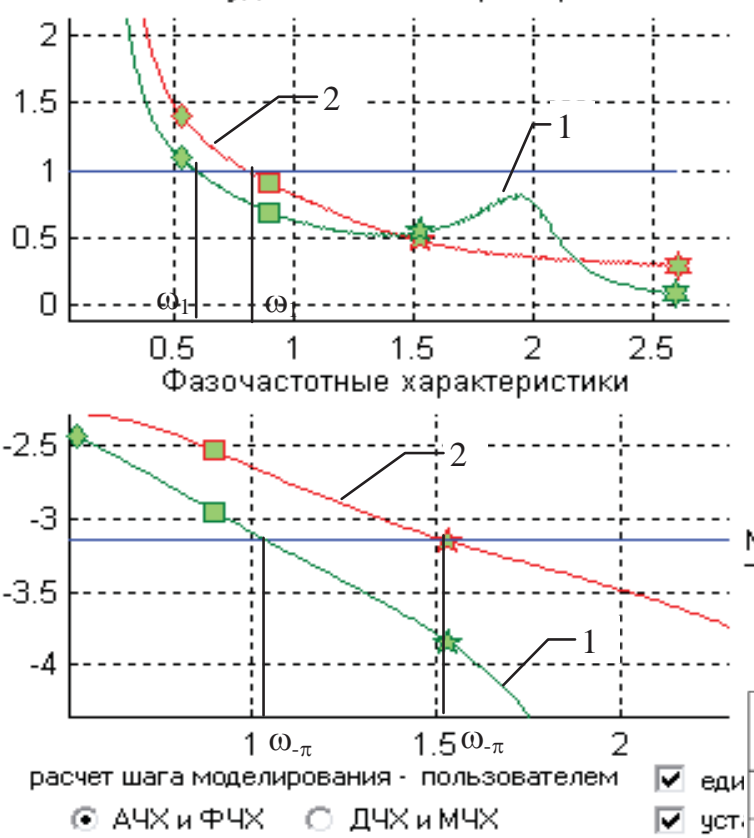

Рисунок Результаты экспериментального or

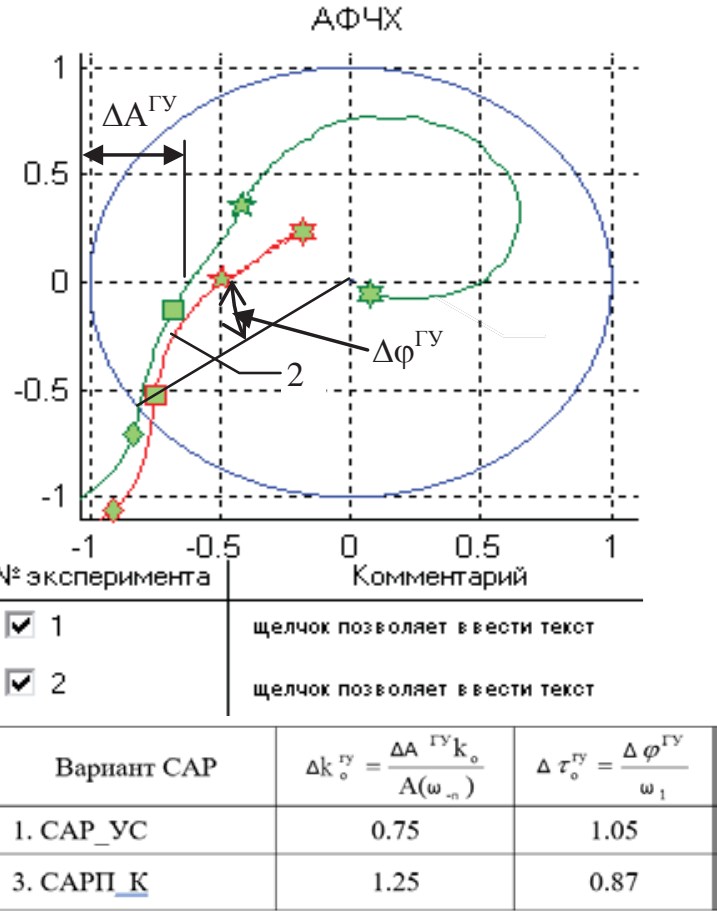

0.87

щелчок позволяет в вести текст

Рис. 15 - Частотні характеристики розімкнутих САР з розрахунком значень їх запасів стійкості за коефіцієнтом передачі $\Delta \mathrm{k}_{0}^{\mathrm{ry}} \mathrm{i}$ часом запізнення $\Delta \underset{\mathrm{f}}{\mathrm{y}}$ в моделі ОК (1 - САР_УC, 2-САРП_К). 

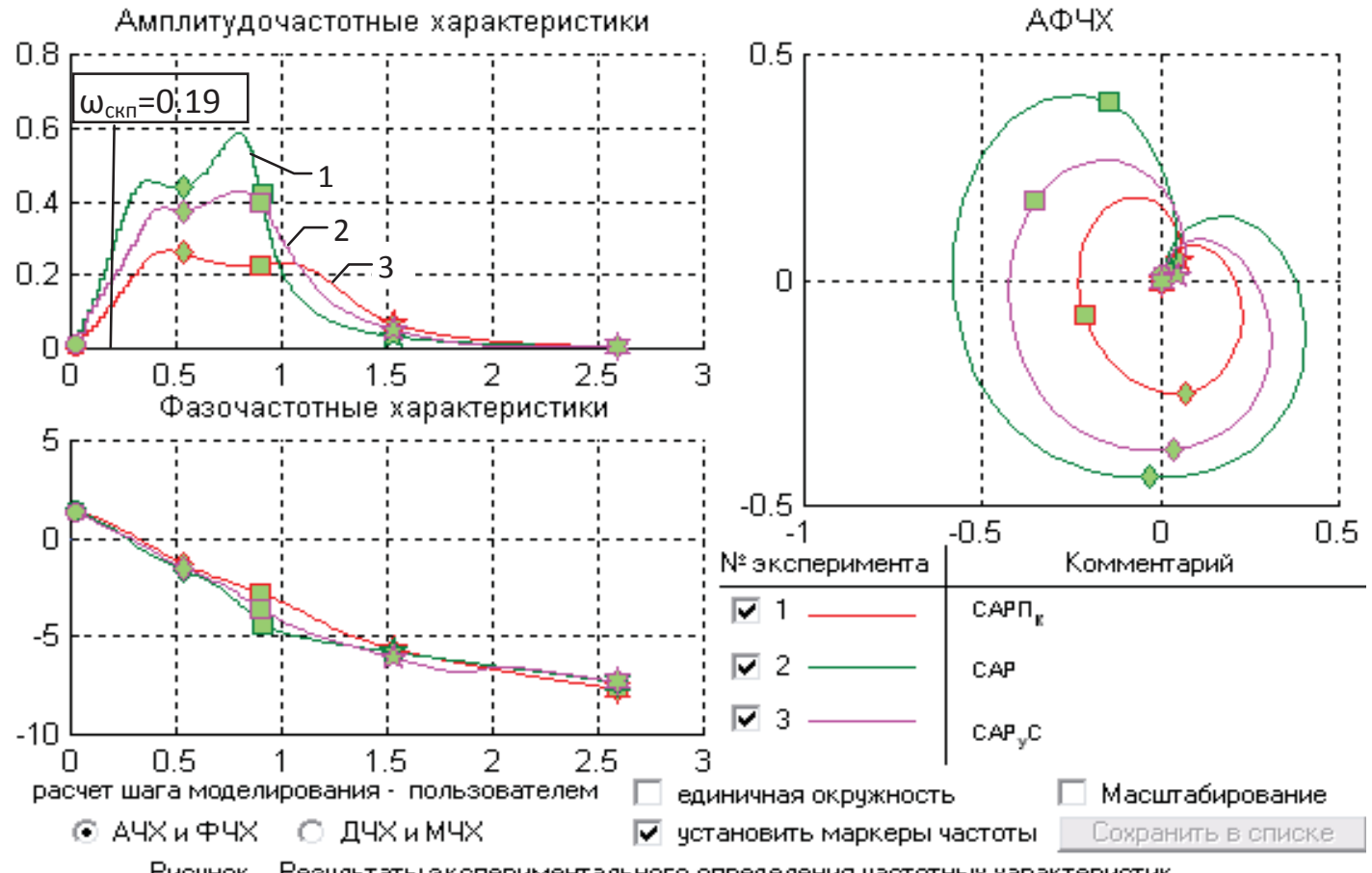

Рисунок Результатызкспериментального определения частотных характеристик

щелчок позволяет в вести текст

Рис. 16 - Частотні характеристики замкнутих оптимальних САР за каналом дії неконтрольованих збурень. (1 САР, 2-CAP_УС, 3-САРП_К; $\omega_{\text {скп }}$ - середньоквадратична частота неконтрольованих збурень )

\section{Висновки}

САР з прогнозуючою моделлю з типовим алгоритмом налаштування забезпечує високий запас стійкості системи i зменшення динамічних похибок за каналом завдання. Динамічна точність за каналом дії неконтрольованих збурень залишається низкою. Введення в САР з ПІД регулятором упереджувача Сміту без додаткових налаштувань також значно розширює іiі запас стійкості. Динамічна точність системи (при фіксованих значеннях параметрів ОК) за каналами завдання та неконтрольованих збурень відповідає динамічній точності САР з прогнозуючою моделлю. Введення в САР алгоритму прогнозуванням за кубічним сплайном підвищує динамічну точність системи за каналом дії неконтрольованих збурень і розширює запас стійкості системи але значно менше ніж системи 3 прогнозуючою моделлю та упереджувачем Сміту. Таким чином якщо ціллю є значне підвищення запасу стійкості системи то потрібно обрати САР з прогнозуючою моделлю чи з упереджувачем Сміту. Якщо ціллю є висока динамічна точність стабілізації при одночасному забезпеченні грубості САР в певному діапазоні змін параметрів ОК, то доцільно використовувати САР з алгоритмом прогнозуванням за кубічним сплайном. Результати оптимального параметричного синтезу проведеного в умовах параметричної невизначеності ОК підтвердили перевагу САР з прогнозуванням за кубічним сплайном перед САР з упереджувачем Сміта в зменшенні похибок стабілізації. САР з прогнозуванням за кубічним сплайном забезпечує зниження максимального динамічного відхилення приблизно на $40 \%$ та інтегрального показника якості у 3 рази в порівнянні з САР 3 упереджувачем Сміта. При цьому запаси стійкості цих систем за коефіцієнтом передачі та часом запізнення були майже однакові.

\section{Список використаних джерел}

[1] O. J. M. Smith. A controller to overcome dead-time. ISA Transactions, 6 (2):28-33, 1959.

[2] J. Rodriguez and P. Cortes. Predictive Control of Power Converters and Electrical Drives. Chichester, UK: Wiley-IEEE Press, 2012. https://doi.org/10.1002/9781119941446

[3] Eduardo F. Camacho and Carlos Bordons Alba. Model predictive control. Springer Science \& Business Media, 2013.

[4] Степанов М.Т., Хобин В.А. Прогнозирование вынужденного движения и его применение в системах гарантирующего управления //Автоматизація технологічних і бізнес-процесів. - Одеса, 2011. - № 5-6. - С. 20 25.

[5] Пикина Г.А., Кузнецов М.С. Синтез линейных прогностических алгоритмов регулирования // Новое в российской электроэнергетике. 2009. № 10. С. 40-44.

[6] Пикина Г.А., Кузнецов М.С. Прогностические типовые алгоритмы регулирования // Теплоэнергетика. 2011. № 4. C. 61-66.

[7] Степанов М.Т., Хобин В.А. Система автоматичного регулювання інваріантна до контрольованих збурень 3 прогнозуванням сигналу корекції по кубічному сплайну // Автоматизація технологічних і бізнес-процесів. Одеса, 2020. - № 1. - Т. 12. - С. $64-70$. 


\title{
References
}

[1] O. J. M. Smith. A controller to overcome dead-time. ISA Transactions, 6 (2):28-33, 1959.

[2] J. Rodriguez and P. Cortes. Predictive Control of Power Converters and Electrical Drives. Chichester, UK: Wiley-IEEE Press, 2012. https://doi.org/10.1002/9781119941446

[3] Eduardo F. Camacho and Carlos Bordons Alba. Model predictive control. Springer Science \& Business Media, 2013.

[4] M.T. Stepanov et al. "Prognozirovanie vyinuzhdennogo dvizheniya i ego primenenie v sistemah garantiruyuschego upravleniya”, Avtomatizatsiya tehnologichnih ta biznes-protsesiv”, no.5-6, pp.20-25, 2011.

[5] G.A. Pikina et al. "Sintez lineynyih prognosticheskih algoritmov regulirovaniya", Novoe v rossiyskoy elektroenergetike 2009, vol. 10. pp. 40-44.

[6] G.A. Pikina et al. "Prognosticheskie tipovyie algoritmyi regulirovaniya”, Teploenergetika 2011, vol. 4. pp. 61-66.

[7] M.T. Stepanov et al. "Systema avtomatychnogo regulyuvannya invariantna do kontrolovanyx zburen z prognozuvannyam sygnalu korekciyi po kubichnomu splajnu”, Avtomatizatsiya tehnologichnih ta biznes-protsesiv”, no.1, vol 12, pp.64-70, 2020.

Отримана в редакції 19.08.2021. Прийнята до друку 27.08.2021. Received 19 August 2021. Approved 27 August 2021.

Available in Internet 31 September 2021.

\section{АНАЛІЗ ЧИННИКІВ, ЩО ВПЛИВАЮТЬ НА УСПІШНІСТЬ ВЕБ РЕСУРСІВ ПІДРОЗДІЛІВ ЗАКЛАДІВ ВИЩОї ОСВІТИ}

\author{
Селіванова А.В. ${ }^{1}$, Бодюл О.С. ${ }^{2}$, Коробов В.С. ${ }^{3}$ \\ 1,2,3 Одеська національна академія харчових технологій \\ ORCID: ${ }^{10000-0002-3395-1422, ~}{ }^{2} 0000-0001-9925-434 X$ \\ E-mail: 1av_selivanova@ukr.net, bodyulolena@ukr.net², vetkor97@gmail.com³
}

Copyright (C) 2021 by author and the journal “Automation of technological and business - processes”. This work is licensed under the Creative Commons Attribution International License (CC BY). http://creativecommons.org/licanses/by/4.0

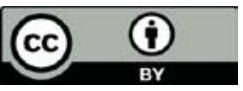

\section{ONAFT}

Open Access

DOI:

\footnotetext{
Анотація. У статті розглядається прочес виявлення та дослідження чинників, щуо впливають на успішність веб ресурсів підрозділів закладів вищої освіти (3ВО). В процесі дослідження проведено аналіз робіт присвячених ияьому питанню, проведено аналіз існуючих популярних серед користувачів веб ресурсів, виявлено критерії оцінки таких систем. В роботах інших авторів, які проводили аналогічні дослідження, аналізуються чинники, які впливають на підвищення якісного рівня веб-сайтів, доведено, як важливо підвищувати комунікативну функціональність сайту, його відвідуваність та відгук аудиторії. Для досягнення мети, поставленої авторами даної роботи, було проведено опитування серед потенційних споживачів веб ресурсів. Розподіл респондентів за віком та фаховими категоріями дозволило виявити, щзо в основному споживачами сайтів кафедр ЗВО є здобувачі освіти. Аналіз результатів проведеного опитування користувачів сайтів $3 B О$ допоміг виявити чинники, щзо впливають на їх успішність та побудувати модель успішності веб ресурсів підрозділів 3ВО, яка стала важливим інформативним фактором для прийняття рішення про дизайн, елементи та зміст нової веб системи. Розроблена модель впроваджена у процесі розробки нового веб-ресурсу кафедри Інформачійних технологій та кібербезпеки ОНАХТ, щзо забезпечило підвищення ефективності подачі інформації, привабливість та затребуваність зазначеного ресурсу. Отримані в дослідженні результати можуть використовуватися при побудові різноманітних інформаційних ресурсів підрозділів закладів вищої освіти для підвищення їх привабливості, інформативності та відвідуваності. планується подальша робота з вдосконалення розробленої моделі і веб системи, щзо ї̈ використовує.

Abstract. The article considers the process of identifying and researching the factors influencing the success of web resources of higher education institutions (HEIs). In the course of the research the analysis of works devoted to this question is carried out, the analysis of the existing popular among users web resources is carried out, the criteria of an estimation of such systems are revealed. The analysis of the results of the survey of consumers of web resources of free economic education
} 